\title{
Kedudukan Hukum Surat Peringatan (SP) dan Skorsing dalam Proses PHK Buruh/Pekerja
}

\author{
Dede Agus \\ Dosen Fakultas Hukum Universitas Sultan Ageng Tirtayasa, Serang-Banten \\ Correspondence email: de298gus@gmail.com
}

\begin{abstract}
Abstrak, Surat peringatan (SP) merupakan salah satu upaya untuk menghindari terjadinya pemutusan hubungan kerja (PHK) karena dengan tindakan ini pengusaha tidak serta merta memutus hubungan kerja dengan buruh/pekerjanya. Namun dalam praktek keharusan adanya surat peringatan ini sering tidak diindahkan oleh pengusaha, bahkan pengusaha langsung mengeluarkan surat skorsing. Padahal antara surat peringatan dan skorsing memiliki kedudukan hukum yang berbeda. Oleh karena itu, tulisan ini bermaksud mengkaji kedudukan hukum surat peringatan dan skorsing dalam proses PHK buruh/pekerja. Surat peringatan dan skorsing dikeluarkan oleh pengusaha sebelum buruh/pekerja di PHK, namun keduanya juga memiliki perbedaan prinsipil. Jika surat peringatan dilakukan sebelum buruh/pekerja di PHK dalam rangka pembinaan dan pengusaha belum melakukan tindakan proses PHK, maka skorsing juga sebelum buruh/pekerja di PHK tetapi pengusaha sudah melakukan tindakan proses PHK (mengajukan dan menunggu penetapan PHK) dari lembaga penyelesaian perselisihan hubungan industrial (PPHI). Jadi skorsing ini dilakukan ketika proses PHK sedang dilakukan atau dalam rangka menunggu penetapan PHK dari lembaga PPHI.
\end{abstract}

Kata Kunci: Kedudukan Hukum; Surat Peringatan; Skorsing; Pemutusan Hubungan Kerja; Buruh/Pekerja

Abstract, Warning letter (SP) is an effort to avoid layoffs (PHK), because warning letter does not decide an employment relationship immediately. Sometimes, an employer ignore warning letter in practice and they give skorsing letter directly. Although the warning letter and skorsing have a different law status. Therefore, this paper is aimed to discuss warning letter and skorsing law status in labour/an employee layoffs process. Warning letter and skorsing were given labour/an employee by employer before layoffs, but warning letter and skorsing have a difference of principle. Warning letter educate labour/an employee to take responsibility and still not yet layoffs process, but skorsing is given labour/an employee by employer in layoffs process. It propose and wait layoffs decision from institutions of industrial relations disputes settlement.

Keywords: warning letter; law status; skorsing; labour/employee layoffs

\section{PENDAHULUAN}

Hubungan kerja antara buruh/pekerja dengan pengusaha yang dibentuk melalui perjanjian kerja dapat mengalami pemutusan hubungan kerja (PHK). PHK merupakan pengakhiran hubungan kerja karena suatu hal tertentu yang mengakibatkan berakhirnya hak dan kewajiban antara pekerja/buruh dan pengusaha (Pasal 1 angka 25 Undang-undang Nomor 13 Tahun 2003 tentang Ketenagakerjaan). Menurut Halim dalam Abdul Khakim pemutusan hubungan kerja (PHK) adalah suatu langkah pengakhiran hubungan kerja antara buruh/ pekerja dan pengusaha karena suatu hal tertentu (Abdul Khakim, 2003:108). Dengan demikian pemutusan hubungan kerja (PHK) dapat diakibatkan oleh berbagai sebab seperti halnya dikemukakan oleh Sendjun $\mathrm{H}$ Manulang, diantaranya adalah : (1) termination, yaitu pemutusan hubungan kerja karena selesainya atau berakhirnya perjanjian kerja; (2) dismissal, yaitu pemutusan hubungan kerja karena tindakan indisipliner sehingga buruh/pekerja mendapat sanksi pemutusan; (3) redundancy, yaitu pemutusan hubungan kerja karena adanya perkembangan teknologi sehingga menggeser/mengurangi peran buruh/pekerja; dan (4) retrenchment, yaitu pemutusan hubungan kerja karena masalah-masalah ekonomi seperti : resesi ekonomi, krisis moneter (Sendjun H Manulang, 2001:107).
Pemutusan hubungan kerja (PHK) dapat berdampak negatif dan positif bagi buruh/pekerja maupun pengusaha. Dampak negatif bagi buruh/pekerja hilangnya salah satu cara memperoleh pendapatan/penghasilan dan secara umum merupakan kesengsaraan bagi buruh/pekerja yang bersangkutan. Dampak positif timbul apabila buruh/pekerja sudah merasa lelah dan bosan untuk bekerja di bawah pimpinan pengusaha. Dampak negatif pemutusan hubungan kerja bagi pengusaha adalah hilang/berkurangnya sumber daya manusia yang dimilikinya, padahal sumber daya manusia merupakan aset berharga perusahaan. Tidak mudah dan murah untuk mendidik, melatih buruh/pekerja agar terampil dan berkualitas. Dampak positif pemutusan hubungan kerja bagi pengusaha berkurangnya beban finansial yang harus ditanggung pengusaha atau non finansial hilangnya/berkurangnya buruh/pekerja yang kurang berkualitas.

Meskipun pemutusan hubungan kerja (PHK) dapat berdampak positif bagi buruh/pekerja maupun pengusaha, namun dampak negatiflah yang lebih besar, maka PHK ditempuh sebagai jalan terakhir setelah sebelumnya semua pihak (pengusaha, pekerja/buruh, serikat pekerja/serikat buruh) harus melakukan upaya untuk menghindari terjadinya pemutusan hubungan kerja 
(PHK). Oleh karena itu, dalam hal buruh/pekerja melakukan pelanggaran ketentuan yang diatur dalam perjanjian kerja, peraturan perusahaan atau perjanjian kerja bersama, pengusaha dapat melakukan pemutusan hubungan kerja, setelah kepada pekerja/buruh yang bersangkutan diberikan surat peringatan pertama, kedua, dan ketiga secara berturut-turut. Surat peringatan (SP) merupakan salah satu upaya untuk menghindari terjadinya pemutusan hubungan kerja (PHK) karena dengan tindakan ini pengusaha tidak serta merta memutus hubungan kerja dengan buruh/pekerjanya. Adanya surat peringatan (SP) membantu agar PHK tidak terjadi secara mendadak, atau bahkan karyawan memperbaiki kinerjanya dan mencapai standar yang telah ditetapkan oleh perusahaan (Syiti Rommalla, 2018:2). Surat peringatan ini masing-masing berlaku untuk paling lama 6 (enam) bulan, kecuali ditetapkan lain dalam perjanjian kerja, peraturan perusahaan atau perjanjian kerja bersama (Pasal 161 ayat (1) dan (2) UU No.13 Tahun 2003). Dalam praktek keharusan adanya surat peringatan (SP) ini sering tidak diindahkan oleh pengusaha, bahkan pengusaha langsung mengeluarkan surat skorsing. Seperti dalam kasus perselisihan PHK buruh/pekerja di perusahaan Garuda Indonesia (PT. Garuda Indonesia) yang telah diputus oleh Hakim Pengadilan Hubungan Industrial (PHI) Jakarta Pusat dalam Putusan No. 01/PHI.G/2006/PN.JKT.PST. Dalam kasus ini buruh/pekerja di PHK oleh pengusaha dengan alasan telah melakukan pelanggaran disiplin tingkat III sebagaimana diatur dalam peraturan kerja bersama (PKB), namun oleh majelis hakim dalam putusannya dinyatakan bahwa perbuatan pengusaha ini bertentangan dengan Undang-undang Ketenagakerjaan (UU No.13 Tahun 2003) dan menyatakan bahwa PHK yang dilakukan terhadap buruh/pekerja batal demi hukum. Demikian pula dalam pertimbangan hukum majelis hakim PHI Serang No.18/G/2006/PHI.Serang tentang Perkara Perselisihan Hubungan Industrial di PT. Teijin Indonesia Fiber Corporation TBK (PT. TIFICO) Tangerang, disebutkan bahwa kalaupun penggugat (pengusaha) merasa bahwa hubungan kerja dengan tergugat (buruh/pekerja) sudah tidak ada lagi keserasian, maka tindakan yang harus dilakukan oleh penggugat kepada tergugat adalah memberikan surat peringatan terlebih dahulu sebagaimana diatur dalam Pasal 161 ayat (1) UU No.13 Tahun 2003 tentang Ketenagakerjaan sebelum sampai pada tindakan skorsing.

Oleh karena dalam praktek keharusan adanya surat peringatan (SP) ini sering tidak diindahkan oleh pengusaha, bahkan pengusaha langsung mengeluarkan surat skorsing, padahal antara surat peringatan (SP) dan skorsing memiliki kedudukan hukum yang berbeda. Oleh karena itu, agar tidak terjadi salah penafsiran dan penerapan hukum dalam praktek perlu pengkajian jelas tentang kedudukan hukum surat peringatan (SP) dan skorsing tersebut.
Berdasarkan latar belakang di atas, maka batasan masalah dalam penelitian/tulisan ini adalah bagaimana kedudukan hukum surat peringatan (SP) dan skorsing dalam proses pemutusan hubungan kerja (PHK) buruh/pekerja. Hal ini dalam rangka menghindari penafsiran dan penerapan hukum yang salah dalam proses pemutusan hubungan kerja buruh/pekerja.

\section{HASIL DAN PEMBAHASAN \\ Prosedur Pemutusan Hubungan Kerja (PHK)}

Meskipun pemutusan hubungan kerja (PHK) dapat berdampak positif bagi buruh/pekerja maupun pengusaha, namun dampak negatiflah yang lebih besar, yang menurut Abdul Khakim bahwa pemutusan hubungan kerja (PHK) bagi buruh/pekerja merupakan awal hilangnya mata pencaharian, yang berarti buruh/pekerja kehilangan pekerjaan dan penghasilan. Oleh karenanya PHK bisa menjadi momok bagi setiap buruh/pekerja, karena mereka dan keluarganya terancam kelangsungan hidupnya dan merasakan dampak dari PHK serta realita bahwa tidak mudah mencari pekerjaan (Abdul Khakim, 2003:105). Oleh karena itu, dalam rangka meminimalisir dampak negatif serta menciptakan keadilan akibat PHK bagi para pihak baik pengusaha yang melakukan PHK maupun buruh/pekerja yang di PHK maka peraturan perundang-undangan ketenagakerjaan telah mengatur tentang tata cara atau prosedur pemutusan hubungan kerja (PHK) melalui Undang-undang Nomor 13 Tahun 2003 tentang Ketenagakerjaan dan Undang-undang Nomor 2 Tahun 2004 tentang Penyelesaian Perselisihan Hubungan Industrial. Adapun tata cara atau prosedur pemutusan hubungan kerja (PHK) adalah:

a. Sebelumnya semua pihak (pengusaha, pekerja/buruh, serikat pekerja/serikat buruh) harus melakukan upaya untuk menghindari terjadinya pemutusan hubungan kerja (PHK) (Pasal 151 ayat (1) UU No.13 Tahun 2003 tentang Ketenagakerjaan).

b. Dalam hal segala upaya telah dilakukan, namun PHK tidak dapat dihindari, pengusaha dan serikat pekerja/serikat buruh atau pekerja/buruh mengadakan perundingan (Pasal 151 ayat (2) UU No.13 Tahun 2003 tentang Ketenagakeraan).

c. Jika perundingan berhasil, buat persetujuan bersama.

d. Bila tidak berhasil, pengusaha mengajukan permohonan penetapan disertai dasar dan alasanalasannya kepada lembaga penyelesaian perselisihan hubungan industrial (Pasal 151 ayat (3) UU No.13 Tahun 2003 tentang Ketenagakerjaan).

e. Penetapan PHK diberikan oleh lembaga penyelesaian perselisihan hubungan industrial jika maksud PHK telah dirundingkan tetapi gagal (Pasal 152 ayat (3) UU No.13 Tahun 2003 tentang Ketenagakerjaan).

f. PHK tanpa penetapan dari lembaga penyelesaian perselisihan hubungan industrial (PPHI) batal demi hukum, pengecualiannya PHK tanpa penetapan dari lembaga PPHI (Pasal 154 dan 155 UU No.13 Tahun 
2003) adalah : (i) PHK karena alasan pengunduran diri; (ii) PHK karena buruh/pekerja meninggal dunia; (iii) PHK karena buruh/pekerja telah memasuki usia pensiun.

g. Selama belum ada penetapan/putusan dari lembaga penyelesaian perselisihan hubungan industrial, kedua belah pihak tetap melaksanakan segala kewajiban masing-masing, dimana pekerja/buruh tetap menjalankan pekerjaannya dan pengusaha membayar upah (Pasal 155 ayat (2) UU No.13 Tahun 2003 tentang Ketenagakerjaan). Penyimpangan dari ketentuan tersebut adalah pengusaha dapat melaksanakan skorsing pada buruh/pekerja yang sedang dalam proses PHK dengan tetap membayar upah dan hak-hak buruh (Pasal 155 ayat (3) UU No.13 Tahun 2003 tentang Ketenagakerjaan).

Apabila digambarkan dalam bagan tata cara/prosedur pemutusan hubungan kerja (PHK) adalah sebagai berikut (Abdul Khakim, 2003:116):

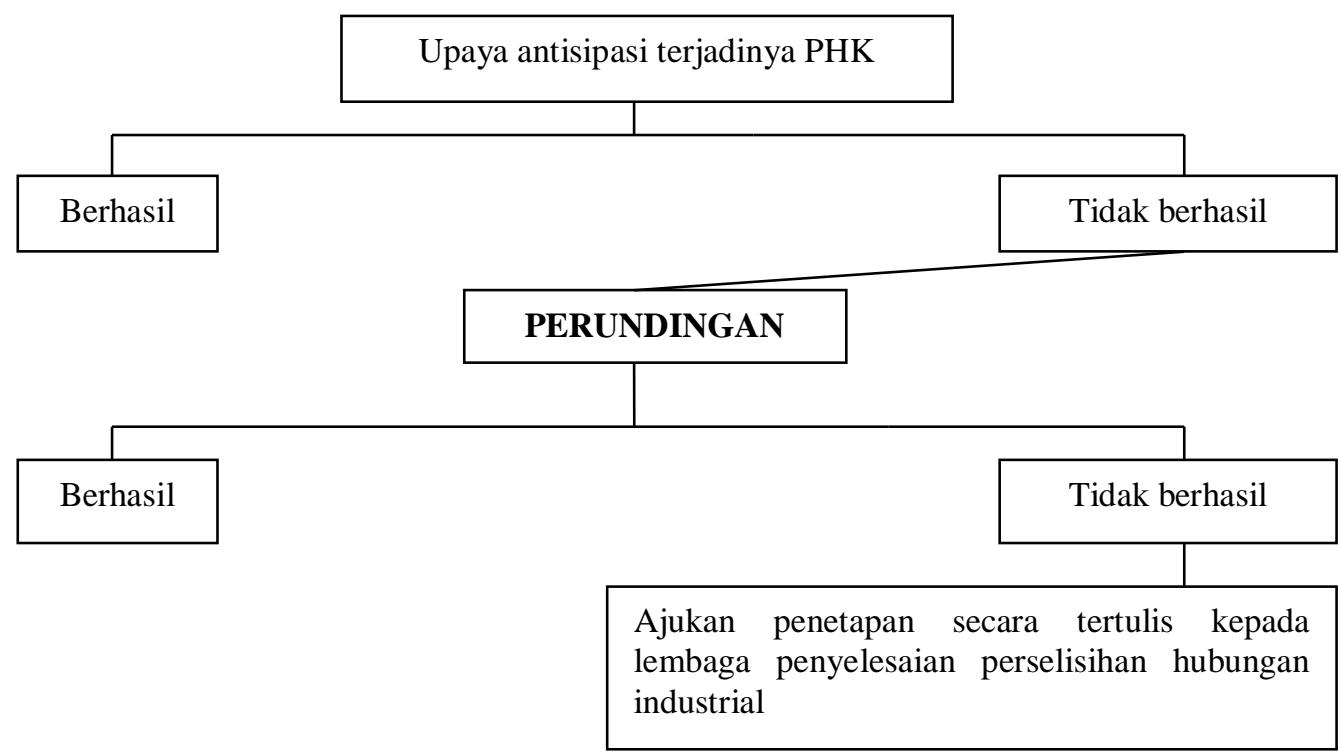

\section{Perselisihan Pemutusan Hubungan Kerja (PHK) dan Upaya Penyelesaiannya}

Pemutusan hubungan kerja (PHK) yang dilakukan oleh para pihak dapat menimbulkan perselisihan pemutusan hubungan kerja (PHK). Perselisihan pemutusan hubungan kerja adalah perselisihan yang timbul karena tidak adanya kesesuaian pendapat mengenai pengakhiran hubungan kerja yang dilakukan oleh salah satu pihak. Menurut M Hadi Shubhan perselisihan PHK merupakan salah satu perselisihan perburuhan yang paling krusial karena semua perselisihan kebanyakan berakhir dengan PHK. Hal tersebut karena posisi pengusaha yang berbeda dibanding buruh/pekerja. Ibaratnya yang punya "rumah" (perusahaan) adalah pengusaha dan buruh/pekerja hanyalah "tamu" yang harus tunduk pada keinginan "tuan rumah"(M. Hadi Shubhan, 2006:3).

Perselisihan pemutusan hubungan kerja (PHK) merupakan salah satu jenis dari perselisihan hubungan industrial. Perselisihan hubungan industrial adalah perbedaan pendapat yang mengakibatkan pertentangan antara pengusaha atau gabungan pengusaha dengan pekerja/buruh atau serikat pekerja/serikat buruh karena adanya perselisihan mengenai hak, perselisihan kepentingan, perselisihan pemutusan hubungan kerja dan perselisihan antar serikat pekerja/serikat buruh dalam satu perusahaan (Pasal 1 angka 1 UU No. 2 Tahun 2004 tentang Penyelesaian Perselisihan Hubungan Industrial). Dari pengertian perselisihan tersebut maka perselisihan hubungan industrial meliputi: perselisihan hak, perselisihan kepentingan, perselisihan pemutusan hubungan kerja (PHK) dan perselisihan antar serikat pekerja/serikat buruh hanya dalam satu perusahaan.

Perselisihan-perselisihan seperti di atas perlu diminimalisir atau dicarikan penyelesaiannya agar konflik tidak menimbulkan ekses-ekses negatif. Penyelesaian konflik itu perlu dilakukan secara cepat, tepat, adil dan murah agar hubungan industrial yang harmonis, dinamis, dan berkeadilan tetap terwujud secara optimal sesuai dengan nilai-nilai Pancasila. Hubungan industrial adalah suatu sistem hubungan yang terbentuk antara para pelaku dalam proses produksi barang dan/atau jasa yang terdiri dari unsur pengusaha, pekerja/buruh, dan pemerintah yang didasarkan pada nilai-nilai Pancasila dan Undang-undang Dasar Negara Republik Indonesia Tahun 1945 (Pasal 1 angka 16 UU No. 13 Tahun 2003 tentang Ketenagakerjaan).

Dalam penyelesaian perselisihan pemutusan hubungan kerja (PHK) dapat dilakukan melalui penyelesaian di luar pengadilan (non litigasi) atau Alternatif Dispute Resolution (ADR) dan penyelesaian melalui pengadilan hubungan industrial (litigasi) (Lalu Husni, 2005:39 dan 81). Penyelesaian sengketa non litigasi dapat ditempuh mulai dari penyelesaian oleh para pihak secara koopratif, dengan bantuan orang lain atau pihak ketiga yang bersifat netral (mediasi, konsiliasi). Penyelesaian konflik atau sengketa melalui pengadilan (litigasi) biasanya ditempuh jika 
penyelesaian sengketa non litigasi tidak mencapai hasil yang diharapkan atau memuaskan para pihak yang berselisih. Adapun mekanisme penyelesaian perselisihan pemutusan hubungan kerja (PHK) adalah sebagai berikut:

1. Penyelesaian Perselisihan Pemutusan Hubungan Kerja (PHK) Secara Bipartit :

a. Perselisihan pemutusan hubungan kerja (PHK) wajib diupayakan penyelesaiannya terlebih dahulu melalui perundingan bipartit secara musyawarah untuk mencapai mufakat (Pasal 3 ayat (1) UU No.2 Tahun 2004 tentang Penyelesaian Perselisihan Hubungan Industrial);

b. Penyelesaian bipartit harus diselesaikan paling lama 30 (tiga puluh) hari sejak dimulainya perundingan (Pasal 3 ayat (2) UU No.2 Tahun 2004 tentang Penyelesaian Perselisihan Hubungan Industrial);

c. Jika 30 (tiga puluh) hari terlampaui maka perundingan bipartit dianggap gagal (Pasal 3 ayat (3) UU No.2 Tahun 2004 tentang Penyelesaian Perselisihan Hubungan Industrial);

d. Jika bipartit mencapai kesepakatan maka dibuat perjanjian bersama (PB) yang ditandatangani para pihak dan wajib dilaksanakan (Pasal 7 ayat (1) dan (2) UU No.2 Tahun 2004 tentang Penyelesaian Perselisihan Hubungan Industrial);

e. Perjanjian bersama (PB) wajib didaftarkan di pengadilan hubungan industrial (PHI) (Pasal 7 ayat (3) dan (4) UU No.2 Tahun 2004 tentang Penyelesaian Perselisihan Hubungan Industrial);

f. Jika ada pihak yang melanggar kesepakatan, maka yang dirugikan dapat mengajukan permohonan eksekusi ke pengadilan hubungan industrial (Pasal 7 ayat (5) dan (6) UU No.2 Tahun 2004 tentang Penyelesaian Perselisihan Hubungan Industrial);

2. Pencatatan Perselisihan Pemutusan Hubungan Kerja (PHK) :

a. Dalam hal perundingan bipartit gagal, maka pihak-pihak mencatatkan perselisihan pemutusan hubungan kerja (PHK) pada Dinas Ketenagakerjaan setempat disertai dengan buktibukti (Pasal 4 ayat (1) dan (2) UU No.2 Tahun 2004 tentang Penyelesaian Perselisihan Hubungan Industrial);

b. Instansi Disnaker menawarkan penyelesaian Perselisihan pemutusan hubungan kerja (PHK) melalui konsiliasi (Pasal 4 ayat (3) dan (5) UU No.2 Tahun 2004 tentang Penyelesaian Perselisihan Hubungan Industrial);

c. Jika tidak dipilih, maka dalam waktu 7 (tujuh) hari pegawai Disnaker melimpahkan penyelesaian perselisihan pemutusan hubungan kerja (PHK) kepada mediator (Pasal 4 ayat (4) UU No.2 Tahun 2004 tentang Penyelesaian Perselisihan Hubungan Industrial);
3. Penyelesaian Perselisihan Pemutusan Hubungan Kerja (PHK) Melalui Konsiliasi :

a. Konsiliasi adalah penyelesaian perselisihan kepentingan, perselisihan PHK, atau perselisihan antar serikat pekerja/serikat buruh dalam satu perusahaan, melalui musyawarah yang ditengahi oleh konsiliator yang netral (Pasal 1 angka 13 UU No.2 Tahun 2004 tentang Penyelesaian Perselisihan Hubungan Industrial);

b. Jika terjadi kesepakatan melalui konsiliasi, maka dibuat perjanjian bersama (PB), kemudian PB didaftarkan di Pengadilan Hubungan Industrial (Pasal 23 ayat (1) UU No.2 Tahun 2004 tentang Penyelesaian Perselisihan Hubungan Industrial);

c. Jika PB tersebut tidak dijalankan oleh salah satu pihak, maka dapat dimintakan eksekusinya di pengadilan hubungan industrial (Pasal 23 ayat (3b) UU No.2 Tahun 2004 tentang Penyelesaian Perselisihan Hubungan Industrial);

d. Jika tidak dapat diselesaikan secara damai, maka konsiliator mengeluarkan anjuran tertulis. Jika anjuran tertulis itu ditolak, maka perselisihan pemutusan hubungan kerja (PHK) dapat dilanjutkan ke Pengadilan Hubungan Industrial (Pasal 23 ayat (2) dan (24) UU No.2 Tahun 2004 tentang Penyelesaian Perselisihan Hubungan Industrial);

4. Penyelesaian Perselisihan Pemutusan Hubungan Kerja (PHK) Melalui Mediasi :

a. Mediasi adalah penyelesaian perselisihan hak, perselisihan kepentingan, perselisihan PHK, dan perselisihan antar serikat pekerja/serikat buruh dalam satu perusahaan, melalui musyawarah yang ditengahi oleh mediator yang netral (Pasal 1 angka 11 UU No.2 Tahun 2004 tentang Penyelesaian Perselisihan Hubungan Industrial);

b. Apabila tidak ada kesepakatan penyelesaian perselisihan pemutusan hubungan kerja (PHK) melalui konsiliasi, maka sebelum ke PHI terlebih dahulu diselesaikan melalui mediasi (Pasal 4 ayat (4) UU No.2 Tahun 2004 tentang Penyelesaian Perselisihan Hubungan Industrial);

c. Jika terjadi kesepakatan melalui mediasi, maka dibuat perjanjian bersama (PB), kemudian PB didaftarkan di Pengadilan Hubungan Industrial (Pasal 13 ayat (1) UU No.2 Tahun 2004 tentang Penyelesaian Perselisihan Hubungan Industrial);

d. Jika tidak dapat diselesaikan secara damai, maka mediator mengeluarkan anjuran tertulis. Jika anjuran tertulis itu ditolak, maka penyelesaian perselisihan pemutusan hubungan kerja (PHK) dapat dilanjutkan ke Pengadilan Hubungan Industrial (PHI) (Pasal 13 ayat (2) dan (14) UU No.2 Tahun 2004 tentang Penyelesaian Perselisihan Hubungan Industrial);

5. Pengadilan Hubungan Industrial (Kompetensi Absolut PHI) : (i) Tingkat I tentang Perselisihan Hak; 
(ii) Tingkat I dan akhir tentang Perselisihan Kepentingan; (iii) Tingkat I tentang Perselisihan PHK; dan (iv) Tingkat I dan Akhir antar Serikat Pekerja/Serikat Buruh. Ketentuan-ketentuan pokok penyelesaian perselisihan di pengadilan hubungan industrial (PHI) adalah :

a. Hukum acara yang berlaku di PHI adalah sama dengan yang berlaku di peradilan umum, kecuali yang diatur khusus dalam UU No.2 Tahun 2004 tentang Penyelesaian Perselisihan Hubungan Industrial (PPHI);

b. Untuk nilai gugatan di bawah $\mathrm{Rp} 150.000 .000$ (seratus lima puluh juta rupiah) tidak dikenakan biaya perkara di pengadilan (Pasal 58 UU No.2 Tahun 2004 tentang Penyelesaian Perselisihan Hubungan Industrial);

c. Upaya hukum terhadap putusan PHI adalah langsung Kasasi ke Mahkamah Agung, tidak melalui upaya banding ke Pengadilan Tinggi;

d. Proses Beracara di Pengadilan Hubungan Industrial dengan acara cepat atau dengan acara biasa. e. Pengambilan putusan selambat-lambatnya 50 (lima puluh) hari kerja terhitung sejak sidang pertama (sidang pertama dilakukan dalam waktu paling lama 7 (tujuh) hari kerja sejak penetapan majelis hakim dan majelis hakim ditetapkan selambat-lambatnya 7 (tujuh) hari kerja setelah menerima gugatan (Pasal 88 ayat (1), Pasal 89 ayat (1) dan Pasal 103 UU No.2 Tahun 2004 tentang Penyelesaian Perselisihan Hubungan Industrial);

f. Upaya hukum terhadap PHI : (1) Kasasi ke Mahkamah Agung (MA); (2) Peninjauan Kembali (PK) ke Mahkamah Agung; (3) Permohonan pembatalan arbitrase bukan ke PHI tapi langsung ke Mahkamah Agung.

Dari uraian di atas apabila digambarkan secara singkat mekanisme penyelesaian perselisihan pemutusan hubungan kerja (PHK) dalam bagan adalah sebagai berikut :

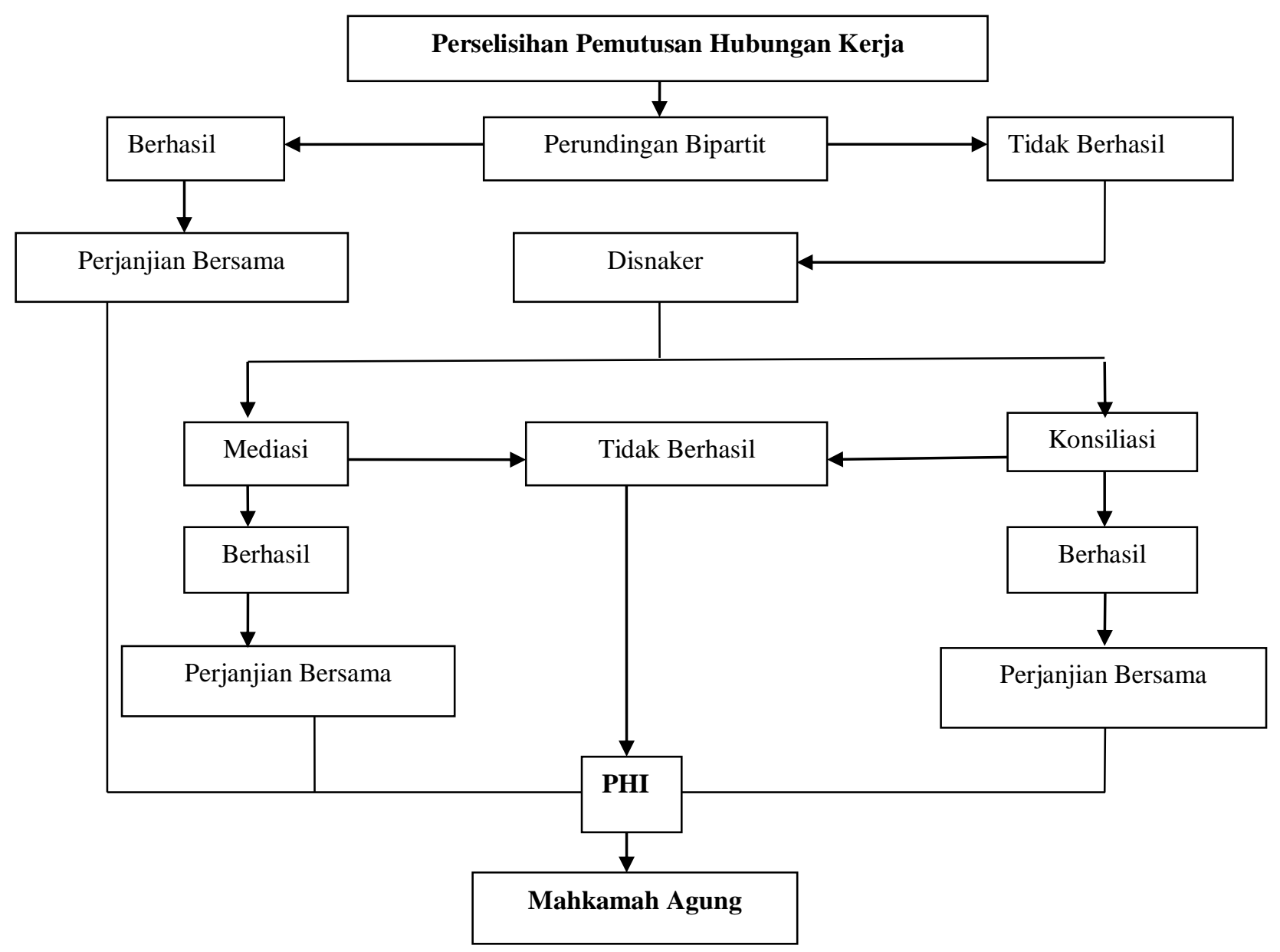

Kedudukan Hukum Surat Peringatan (SP) dan Skorsing dalam Proses PHK

Keharusan adanya surat peringatan (SP) sebelum melakukan PHK terhadap buruh/pekerja adalah telah digariskan oleh Pasal 161 ayat (1) dan (2) UU No.13 Tahun 2003 tentang Ketenagakerjaan, yang mengatur dalam hal buruh/pekerja melakukan pelanggaran ketentuan yang diatur dalam perjanjian kerja, peraturan perusahaan atau perjanjian kerja bersama, pengusaha dapat melakukan pemutusan hubungan kerja (PHK), setelah kepada pekerja/buruh yang bersangkutan diberikan surat peringatan (SP) pertama, kedua, dan 
ketiga secara berturut-turut. Surat peringatan ini masingmasing berlaku untuk paling lama 6 (enam) bulan, kecuali ditetapkan lain dalam perjanjian kerja, peraturan perusahaan atau perjanjian kerja bersama. Jadi apabila pengusaha akan melakukan PHK kepada buruh/pekerjanya harus memberikan surat peringatan (SP) terlebih dahulu. Surat peringatan adalah surat yang berisi tentang peringatan. Peringatan menurut kamus mengandung arti nasihat (teguran) untuk memperingatkan (W.J.S. Poerwadarminta, 2007:446). Dalam hal ini SP, alias surat peringatan, merupakan surat yang dibuat untuk karyawan yang telah melakukan kesalahan atau pelanggaran terhadap aturan perusahaan (Futhuriyyah Mahendra, 2018:2). Dengan adanya surat peringatan (SP) masih memberikan kesempatan kepada buruh/pekerja yang bersangkutan untuk memperbaiki diri dalam bekerja di perusahaan dan kesempatan bagi pengusaha untuk melakukan penilaian terhadap kinerja buruh/pekerja. Dengan kata lain adanya surat peringatan ini adalah perwujudan dari azas pembinaan kepada buruh/pekerja. Pertimbangan hukum majelis hakim dalam Putusan No.01/PHI.G/2006/PN.JKT.PST tentang Perselisihan PHK Buruh/Pekerja di Perusahaan Garuda Indonesia (PT. Garuda Indonesia) menyatakan bahwa tergugat (pengusaha) seharusnya terlebih dahulu memberikan surat peringatan (SP) dalam rangka pembinaan kepada penggugat (buruh/pekerja) sesuai ketentuan Pasal 161 ayat (1) UU No. 13 Tahun 2003 tentang Ketenagakerjaan. Menurut Dimas Hutomo, Surat Peringatan (SP) merupakan suatu bentuk pembinaan perusahaan kepada karyawan sebelum menjatuhkan pemutusan hubungan kerja (PHK) terhadap karyawannya yang berupa surat peringatan kesatu, kedua dan ketiga (Dimas Hutomo, 2019:3). Begitu pula Putusan Majelis Hakim PHI Surabaya No. 44/G/2006/PHI.Surabaya tentang Perselisihan PHK Buruh/Pekerja di PT. Yamaha Musical Products Indonesia (PT.YMP) Pasuruan, menyatakan bahwa apabila tergugat (pengusaha) bermaksud untuk melakukan pemutusan hubungan kerja (PHK) kepada penggugat (buruh/pekerja) maka kepada penggugat terlebih dahulu diberikan sanksi pembinaan berupa surat peringatan. Penjelasan Pasal 161 ayat (2) menyatakan bahwa tenggang waktu 6 (enam bulan) dimaksudkan sebagai upaya mendidik pekerja/buruh agar dapat memperbaiki kesalahannya dan di sisi lain merupakan waktu yang cukup bagi pengusaha untuk melakukan penilaian terhadap kinerja pekerja/buruh. Dimas Hutomo juga menyatakan bahwa tenggang waktu 6 bulan dimaksudkan sebagai upaya mendidik pekerja/buruh agar dapat memperbaiki kesalahannya dan di sisi lain waktu 6 bulan ini merupakan waktu yang cukup bagi pengusaha untuk melakukan penilaian terhadap kinerja pekerja/buruh yang bersangkutan (Dimas Hutomo, 2019:3). Ini tentu saja sesuai dengan makna yang terkandung dalam Pasal 151 ayat (1) UU No.13 tahun 2003 tentang Ketenagakerjaan, yang pada pokoknya sebelum melakukan PHK semua pihak (pengusaha, pekerja/buruh, serikat pekerja/serikat buruh, dan pemerintah) harus melakukan segala upaya untuk menghindari terjadinya pemutusan hubungan kerja (PHK). Penjelasan pasal tersebut menyatakan bahwa yang dimaksud dengan segala upaya adalah kegiatankegiatan yang positif yang pada akhirnya dapat menghindari terjadinya pemutusan hubungan kerja (PHK), antara lain pengaturan waktu kerja, penghematan, pembenahan metode kerja, dan memberikan pembinaan kepada pekerja/buruh. Menurut Libertus Jehani tindakan PHK harus menjadi pilihan terakhir dalam mengatasi masalah perusahaan. Karena itu, sebelum PHK dilakukan harus diupayakan pencegahan yang salah satunya melakukan pembinaan kepada buruh/pekerja berupa surat peringatan (SP I, II dan III) (Libertus Jehani, 2007:14). Hal ini terjadi sebab PHK meskipun dapat berdampak positif namun umumnya dampak negatiflah yang lebih besar terutama bagi buruh/pekerja. Menurut Maimun bagi buruh/pekerja PHK berdampak langsung pada jaminan pendapatan (income security) bagi diri dan keluarganya, sedangkan bagi pengusaha PHK berarti kehilangan buruh/pekerja yang selama ini telah dididik dan memahami prosedur kerja di perusahaannya (Maimun, 2004:71).

Surat peringatan (SP) dan skorsing dikeluarkan oleh pengusaha sebelum buruh/pekerja di PHK, namun keduanya juga memiliki perbedaan prinsipil. Jika surat peringatan (SP) dilakukan sebelum buruh/pekerja di PHK dan pengusaha belum melakukan tindakan proses PHK, maka skorsing juga sebelum buruh/pekerja di PHK tetapi pengusaha sudah melakukan tindakan proses PHK (mengajukan dan menunggu penetapan PHK dari lembaga penyelesaian hubungan industrial). Menurut Dimas Hutomo, tindakan skorsing dikenal UU No. 13 Tahun 2003 tentang Ketenagakerjaan dalam hal pekerja/buruh (karyawan) sedang dalam proses pemutusan hubungan kerja (Dimas Hutomo, 2019:3). Jadi skorsing ini dilakukan ketika proses PHK sedang dilakukan atau dalam rangka menunggu penetapan PHK dari lembaga penyelesaian hubungan industrial. Skorsing menurut kamus adalah pemecatan atau pemberhentian untuk sementara waktu (untuk suatu jangka waktu tertentu) (W.J.S. Poerwadarminta, 2007:1136). Putusan majelis hakim PHI Serang No. 08/G/2007/PHI.Serang tentang Perselisihan PHK Buruh/Pekerja di PT. Karya Cipta Putra Indonesia d/h PT. Internusa Artacipta Tangerang, menyatakan bahwa skorsing yang dilakukan sesuai dengan ketentuan Pasal 155 ayat (3) UU No.13 Tahun 2003 tentang Ketenagakerjaan, maka hubungan kerja antara tergugat (pengusaha) dan penggugat (buruh/pekerja) masih berlanjut sampai dengan dikeluarkannya penetapan dari lembaga PPHI dengan tetap menerima upah dan hak-hak lain yang biasa diterima oleh penggugat (buruh/pekerja). Pasal 155 ayat (2) dan (3) UU No.13 Tahun 2003 pada pokoknya menyatakan bahwa selama putusan lembaga 
penyelesaian perselisihan hubungan industrial belum ditetapkan, baik pengusaha maupun pekerja/buruh harus tetap melaksanakan segala kewajibannya. Ketentuan Pasal 155 ayat (2) UU No.13 Tahun 2003 dilakukan uji materil dan dikabulkan Mahkamah Konstitusi (MK), yaitu dalam Putusan MK No 37/PUU-IX/2011, tentang permohonan Pengujian UU No 13 Tahun 2003 tentang Ketenagakerjaan terhadap UUD 1945, tanggal 19 September 2011, yang amar putusannya menyatakan: Frasa "belum ditetapkan" dalam Pasal 155 ayat (2) UU No 13 Tahun 2003 tentang Ketenagakerjaan bertentangan dengan UUD 1945 dan tidak mempunyai kekuatan hukum mengikat sepanjang tidak dimaknai 'belum berkekuatan hukum tetap'. Jadi anak kalimat "belum ditetapkan" harus dimaknai "belum berkekuatan hukum tetap". Pengusaha dapat melakukan penyimpangan dengan melakukan tindakan skorsing kepada pekerja/buruh yang sedang dalam proses pemutusan hubungan kerja dengan tetap wajib membayar upah beserta hak-hak lainnya yang biasa diterima pekerja/buruh. Putusan majelis hakim PHI Serang menyatakan bahwa skorsing adalah hak tergugat
(Pengusaha) sepanjang dilaksanakan sesuai ketentuan Pasal 155 ayat (3) UU No.13 Tahun 2003 tentang Ketenagakerjaan. Jadi jelas perbedaan prinsipil antara surat peringatan (SP) dan skorsing, jika dalam masa surat peringatan (SP) buruh/pekerja masih aktif bekerja di perusahaan hanya saja sedang dalam masa pembinaan melalui SP (surat peringatan), sedangkan skorsing buruh/pekerja berhenti bekerja sementara waktu (tidak aktif bekerja). Juga surat peringatan (SP) haruslah ditempuh/dilakukan oleh pengusaha jika akan memPHK buruh/pekerja dengan alasan buruh/pekerja melanggar ketentuan dalam perjanjian kerja, peraturan perusahaan atau perjanjian kerja bersama. Sedangkan skorsing boleh dilakukan atau tidak dilakukan oleh pengusaha kepada buruh/pekerjanya. Menurut hukum online pengusaha melakukan tindakan skorsing dengan maksud menghindari adanya perbuatan berlanjut seperti menghilangkan dokumen atau untuk memberikan ruang yang cukup bagi karyawan dalam menjalani proses hokum (Willy Farianto, 2011:1). Untuk lebih jelas tentang kedudukan hukum surat peringatan (SP) dan skorsing dapat dijelaskan melalui bagan di bawah ini :

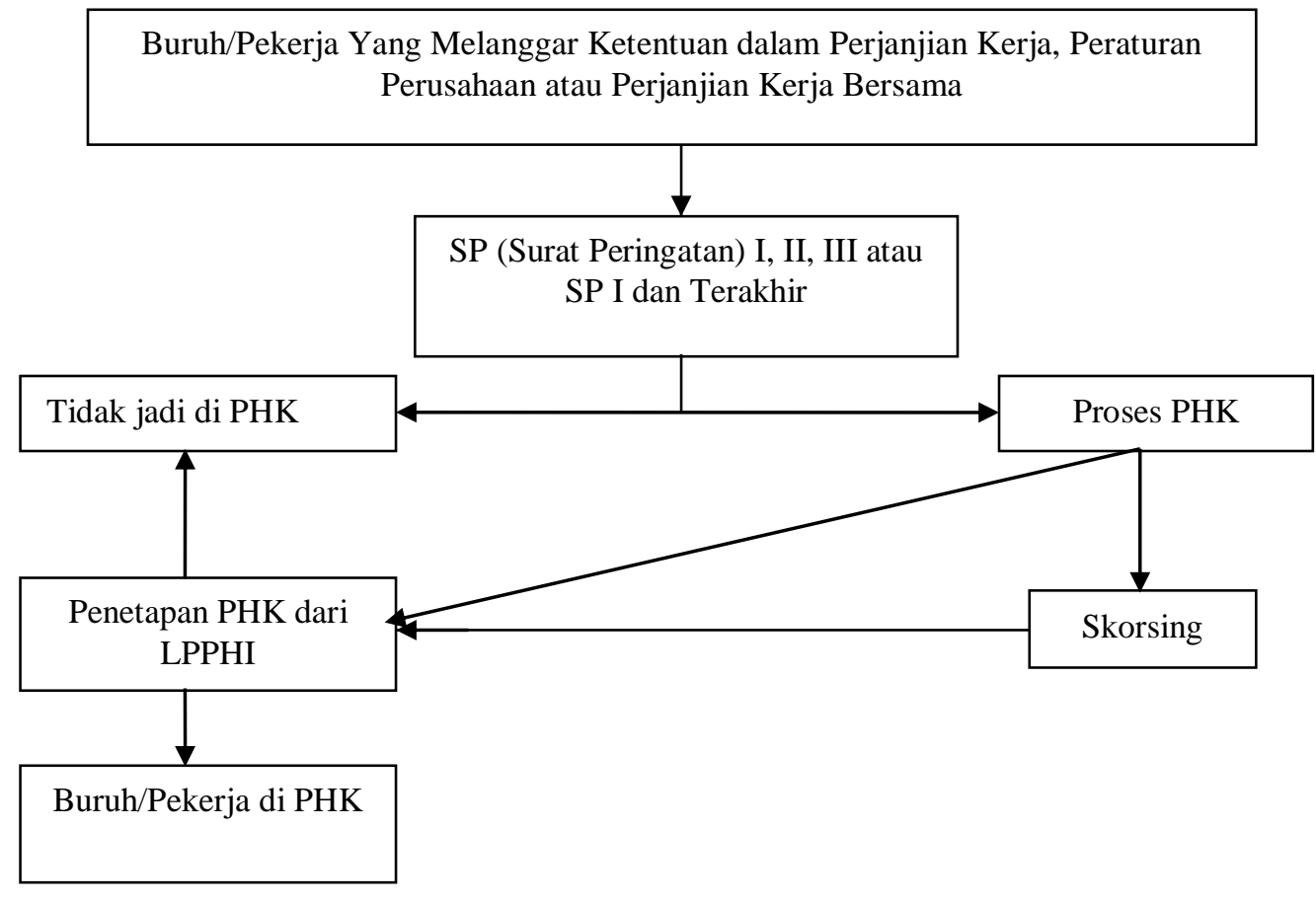

\section{SIMPULAN}

Meskipun pemutusan hubungan kerja (PHK) dapat berdampak positif bagi buruh/pekerja maupun pengusaha, namun dampak negatiflah yang lebih besar, maka PHK ditempuh sebagai jalan terakhir setelah sebelumnya semua pihak (pengusaha, pekerja/buruh, serikat pekerja/serikat buruh) harus melakukan upaya untuk menghindari terjadinya pemutusan hubungan kerja. Oleh karena itu, dalam hal buruh/pekerja melakukan pelanggaran ketentuan yang diatur dalam perjanjian kerja, peraturan perusahaan atau perjanjian kerja bersama, pengusaha dapat melakukan pemutusan hubungan kerja, setelah kepada pekerja/buruh yang bersangkutan diberikan surat peringatan pertama, kedua, dan ketiga secara berturut-turut. Surat peringatan (SP) merupakan salah satu upaya untuk menghindari terjadinya pemutusan hubungan kerja karena dengan tindakan ini pengusaha tidak serta merta memutus hubungan kerja dengan buruh/pekerjanya. Namun dalam praktek keharusan adanya surat peringatan ini sering tidak diindahkan oleh pengusaha, bahkan pengusaha langsung mengeluarkan surat skorsing. Padahal antara surat peringatan dan skorsing memiliki kedudukan hukum yang berbeda, meskipun keduanya dikeluarkan 
oleh pengusaha sebelum buruh/pekerja di PHK, namun keduanya juga memiliki perbedaan prinsipil. Jika surat peringatan dilakukan sebelum buruh/pekerja di PHK dalam rangka pembinaan dan pengusaha belum melakukan tindakan proses PHK, maka skorsing juga sebelum buruh/pekerja di PHK tetapi pengusaha sudah melakukan tindakan proses PHK (mengajukan dan menunggu penetapan PHK dari lembaga penyelesaian perselisihan hubungan industrial). Jadi skorsing ini dilakukan ketika proses PHK sedang dilakukan atau dalam rangka menunggu penetapan PHK dari lembaga penyelesaian hubungan industrial. Disamping itu pada masa surat peringatan (SP) buruh/pekerja masih aktif bekerja di perusahaan hanya saja sedang dalam masa pembinaan melalui SP, sedangkan skorsing buruh/pekerja berhenti bekerja sementara waktu (tidak aktif bekerja).

\section{DAFTAR PUSTAKA}

Farianto, Willy. Problem Hukum Upah Proses Pasca Putusan MK, http://www.hukum.online.com, Selasa, 04 Oktober 2011.

Husni, Lalu. Penyelesaian Perselisihan Hubungan Industrial, RadjaGrafindo Persada: Jakarta, 2005.

Hutomo, Dimas. Hukumnya Mengeluarkan SP 3 Tanpa Bukti Pelanggaran, http://hukumonline.com, Jumat, 19 Juli 2019.

Jehani, Libertus. Hak-hak Pekerja Bila di PHK, VisiMedia: Jakarta, 2007.

Khakim, Abdul. Pengantar Hukum Ketenagakerjaan Indonesia: Berdasarkan UU No. 13 Tahun 2003, Citra Aditya Bakti: Bandung, 2003.

Maimun. Hukum Ketenagakerjaan, Pradnya Paramita: Jakarta, 2004.

Manulang, Sendjun H. Pokok-pokok Hukum Ketenagakerjaan Indonesia, Rineka Cipta: Jakarta, 2001.

Mahendra, Futhuriyyah. Surat Peringatan (SP) Karyawan dan Ketentuannya Menurut UU, https://glints.com/id/lowongan, 27 Juli 2018.

Poerwadarminta,W.J.S. Kamus Umum Bahasa Indonesia, Edisi ketiga cetakan keempat, Balai Pustaka: Jakarta, 2007.

Rommalla, Syiti. Aturan Surat Peringatan Karyawan (SP) berdasarkan Undang-Undang Ketenagakerjaan, https://www.gadjian.com/blog, 16 Maret 2018.

Shubhan, M. Hadi. Bahan Kuliah Hukum Ketenagakerjaan, Fakultas Hukum Universitas Airlangga (Unair): Surabaya, 2006.

Undang-Undang Dasar Negara Republik Indonesia Tahun 1945

Undang-undang Nomor 13 Tahun 2003 tentang Ketenagakerjaan.

Undang-undang No. 2 Tahun 2004 tentang Penyelesaian Perselisihan Hubungan Industrial.
Putusan Mahkamah Konstitusi No 37/PUU-IX/2011, tentang permohonan Pengujian UU No 13 Tahun 2003 tentang Ketenagakerjaan terhadap UUD 1945, tanggal 19 September 2011.

Putusan No. 01/PHI.G/2006/PN.JKT.PST tentang Perselisihan PHK Buruh/Pekerja di Perusahaan Garuda Indonesia (PT. Garuda Indonesia).

Putusan No. 44/G/2006/PHI.Sby tentang Perselisihan PHK Buruh/Pekerja di PT. Yamaha Musical Products Indonesia (PT.YMP) Pasuruan.

Putusan No.18/G/2006/PHI.Serang tentang Perkara Perselisihan Hubungan Industrial di PT. Teijin Indonesia Fiber Corporation TBK (PT. TIFICO) Tangerang.

Putusan No. 08/G/2007/PHI.Serang tentang Perselisihan PHK Buruh/Pekerja di PT. Karya Cipta Putra Indonesia d/h PT. Internusa Artacipta Tangerang. 